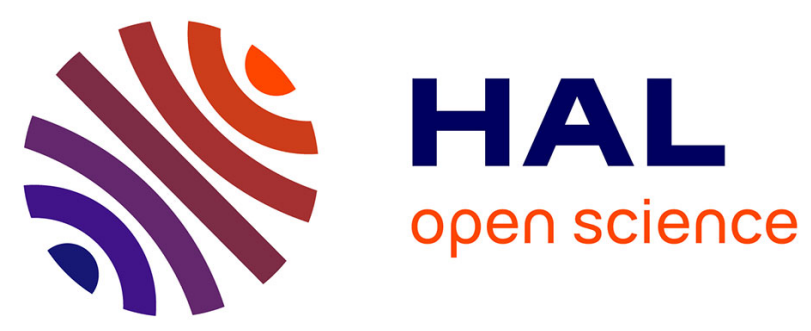

\title{
Activation of human dental pulp progenitor/stem cells in response to odontoblast injury
}

Odile Téclès, Patrick Laurent, Sabine Zygouritsas, Anne-Sophie Burger, Jean Camps, Jacques Dejou, Imad About

\section{To cite this version:}

Odile Téclès, Patrick Laurent, Sabine Zygouritsas, Anne-Sophie Burger, Jean Camps, et al.. Activation of human dental pulp progenitor/stem cells in response to odontoblast injury. Archives of Oral Biology, 2005, 50 (2), pp.103-108. 10.1016/j.archoralbio.2004.11.009 . hal-03552532

\section{HAL Id: hal-03552532 \\ https://hal.science/hal-03552532}

Submitted on 2 Feb 2022

HAL is a multi-disciplinary open access archive for the deposit and dissemination of scientific research documents, whether they are published or not. The documents may come from teaching and research institutions in France or abroad, or from public or private research centers.
L'archive ouverte pluridisciplinaire HAL, est destinée au dépôt et à la diffusion de documents scientifiques de niveau recherche, publiés ou non, émanant des établissements d'enseignement et de recherche français ou étrangers, des laboratoires publics ou privés.

\section{(ㅇ)(1) $\$$}

Distributed under a Creative Commons Attribution - NonCommercial - NoDerivatives $\mid 4.0$ 


\title{
Activation of human dental pulp progenitor/stem cells in response to odontoblast injury
}

\author{
Odile Téclès, Patrick Laurent, Sabine Zygouritsas, \\ Anne-Sophie Burger, Jean Camps, Jacques Dejou, Imad About*
}

\author{
Laboratoire IMEB - ERT 30, Faculté d'Odontologie, Université de la Méditerranée, \\ 27 Boulevard Jean Moulin, 13385 Marseille Cedex 05, France
}

\author{
KEYWORDS \\ Human pulp; \\ Whole tooth culture; \\ Stem cell activation; \\ Migration
}

Summary In restorative dentistry, whilst moderate carious lesion treatment does not significantly compromise odontoblast cell survival, deep cavity preparation may lead to a partial death of these cells. However, newly formed odontoblast-like cells can replace the necrotic odontoblasts and secrete a reparative dentine matrix. Although several lines of evidence strongly suggest the presence of resting progenitor or stem cells in the dental pulp, little is known about the activation and migration of these cells in response to injury.

Human immature third molars extracted for orthodontic reasons were used in this work to study the activation of progenitor/stem cells and their migration after deep cavity preparation involving in pulpal exposure using 5-bromo- $2^{\prime}$-deoxyuridine labelling (BrdU).

After incubation for 1 day, the BrdU was localised to the nuclei of cells in the perivascular area. The BrdU-immunolabelling exhibited a gradient. It was strong in the blood vessels surrounding the pulpal cavity and decreased in those away from the cavity. After incubation for 2 weeks, labelled cells were seen in the vicinity of the cavity. At 4 weeks, the immunolabelling was localised to the cavity area only. Control teeth without cavities or with shallow dentine cavities did not show any perivascular labelling after culture. These results clearly demonstrate that perivascular progenitor/stem cells can proliferate in response to odontoblast injury. They also show that these proliferating cells can migrate to the pulpal injury site in their tissue of origin simulating the situation in vivo.

(C) 2004 Elsevier Ltd. All rights reserved.

\section{Introduction}

Dentinogenesis is regulated by highly differentiated post-mitotic odontoblasts originating from neural crest-derived cells of the dental papilla. ${ }^{1,2}$ In pathological conditions, such as moderate carious lesions, 
the secretory activity of the odontoblasts is stimulated to elaborate reactionary dentine..$^{3-6}$ In contrast, deep cavity preparation leads to odontoblast death. In this case, newly formed odontoblast-like cells can replace the necrotic cells and secrete a reparative dentine matrix. ${ }^{3-6}$

Several lines of evidence strongly suggest the presence of resting progenitor or stem cells in the dental pulp. It has been shown that the adult human dental pulp contains a rapidly proliferative subpopulation of cells capable of differentiating into adipocytes and neural-like cells. ${ }^{7}$ In vitro, they can differentiate into odontoblast-like cells secreting a mineralised matrix having the mineral and molecular characteristics of dentine. ${ }^{8}$ When transplanted into immunocompromised mice, they generated a dentine-like structure lined with odontoblast-like cells that surrounded a pulp-like interstitial tissue. ${ }^{9}$ In transgenic mice that carry the Green Fluorescent Protein (GFP) reporter gene fused to $2.3 \mathrm{~kb}$ fragment of rat Col1a1 regulatory sequence (pOBCol2.3GFPemd), these cells were shown to contain progenitor cells capable of differentiating into odontoblast-like cells expressing high levels of Col1a1-2.3-GFP and DSPP and secrete tubular containing reparative dentine. In the human dental pulp, these cells were localised to the perivascular area. ${ }^{10}$ However, little is known about the activation and migration of these cells in response to dental injury. The objective of this work was to investigate the activation and migration of these progenitor/ stem cells in response to pulpal injury in their tissue of origin.

\section{Materials and methods}

\section{Materials}

For the preparation of the culture media, all materials were purchased from BioWhittaker (Gagny, France). Chemicals were obtained from Sigma Chemicals Corporation (St. Louis, MO) unless otherwise stated.

\section{Teeth}

Human immature third molars freshly extracted for orthodontics reasons were obtained in compliance with French legislation (informed patient consent and Institutional Review Board approval of the protocol used). The teeth were used to study the activation and the migration of pulp progenitor/ stem cells after preparation of pulpal cavities (pulpal exposure) using 5-bromo-2'-deoxyuridine labelling (BrdU).

\section{Antibodies}

Monoclonal antibodies against BrdU were purchased from Sigma Chemicals Co. (St. Louis, MO).

\section{Tooth culture}

The extracted teeth were immediately transported to the laboratory in minimum essential medium (MEM) supplemented with $300 \mathrm{UI} / \mathrm{mL}$ penicillin, $300 \mu \mathrm{g} / \mathrm{mL}$ streptomycin, $0.75 \mu \mathrm{g} / \mathrm{mL}$ amphotericin $B$ (fungizone ${ }^{\circledR}$ ). The teeth were cleaned with sterilised instruments after eliminating the periodontal ligament and the dental sac. Some cavities involved pulpal exposure and others did not. Exposed pulpal occlusal cavities with minimal exposure were prepared with diamond truncated burs mounted on a high-speed (300 $000 \mathrm{rpm})$ dental handpiece (reference 878.2872 diameter 016) and sterile saline cooling.

Teeth without cavities and with shallow dentine cavities (RDT range $1-3 \mathrm{~mm}$ ) were used as controls for the cell proliferation studies. Dentine cavities (without pulpal exposure) were prepared with diamond cylindrical burs mounted on a high-speed $(300000 \mathrm{rpm})$ dental handpiece (reference 878.2863 diameter 023 ) and sterile saline cooling.

The teeth were cultured in four-well-tissue plates (Nunclon, Nunc, Roskilde, Denmark). The crowns were fixed to the cover with sterile wax and the apical part of the teeth was dipped in the culture medium without touching the bottom of the culture wells. All teeth had open apices allowing diffusion of the medium to the pulpal tissues.

The culture medium was MEM supplemented with $10 \%$ fetal bovine serum, $200 \mathrm{UI} / \mathrm{mL}$ penicillin, $200 \mu \mathrm{g} / \mathrm{mL}$ streptomycin, $0.5 \mu \mathrm{g} / \mathrm{mL}$ amphotericin $B$ (fungizone ${ }^{\mathbb{R}}$ ). For the localisation of $\mathrm{BrdU}$, the teeth were incubated with BrdU-containing MEM medium $(1 \mathrm{mg} / \mathrm{mL})$ for 1 day. In order to control the cell migration after pulpal cavity preparation, the teeth were incubated in the BrdU containing MEM medium for 1 day, then, in the same medium without BrdU for different periods: 1 day, 2 weeks and 4 weeks.

\section{Histology}

After the culture periods, the teeth were fixed in a formol $4 \%$ solution and demineralised in a solution of $3.4 \%$ sodium formiate in $17 \%$ formic acid until fully decalcified for histological treatment. Samples were routinely processed through a series of graded alcohols and xylene, and finally embedded in paraffin wax. 


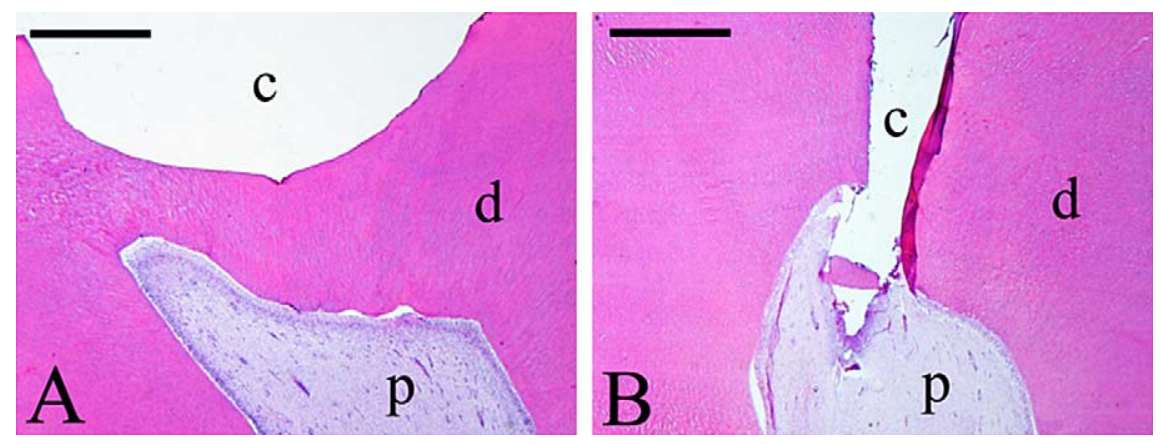

Figure 1 Histological control of cavities. The teeth with dentine (A) and pulpal (B) cavities were routinely processed for histology and stained with haematoxylin-eosin. Abbreviations: c: cavity; d: dentine; p: pulp. Scale bars in (A and B): $1 \mathrm{~mm}$.

\section{Immunohistochemistry}

This was performed on $7-\mu \mathrm{m}$ thick paraffin embedded sections with anti-BrdU monoclonal antibodies. Primary antibodies (anti-BrdU antibodies) were diluted in PBS containing $0.1 \%$ bovine serum albumin (BSA). The incubation with primary antibodies was performed overnight at $4{ }^{\circ} \mathrm{C}$ at $10 \mu \mathrm{g} /$ $\mathrm{mL}$. The immunostaining was revealed using the labelled streptavidin-biotin kit (LSAB; Dako Corp., Carpinteria, CA) according to the manufacturer's instructions. Controls with unrelated primary antibodies were negative.

\section{Results}

Haematoxylin-eosin staining of the teeth (Fig. 1) after the dentine (A) and pulp cavity preparation (B) showed a residual dentine barrier at the cavity floor after dentine cavity preparation while pulp exposure was seen after pulpal cavity preparation.

\section{Progenitor/stem cell proliferation}

After pulpal cavity preparation and incubation with BrdU for 1 day, labelling was localised to the nuclei of cells in the perivascular area. The BrdU-immu-
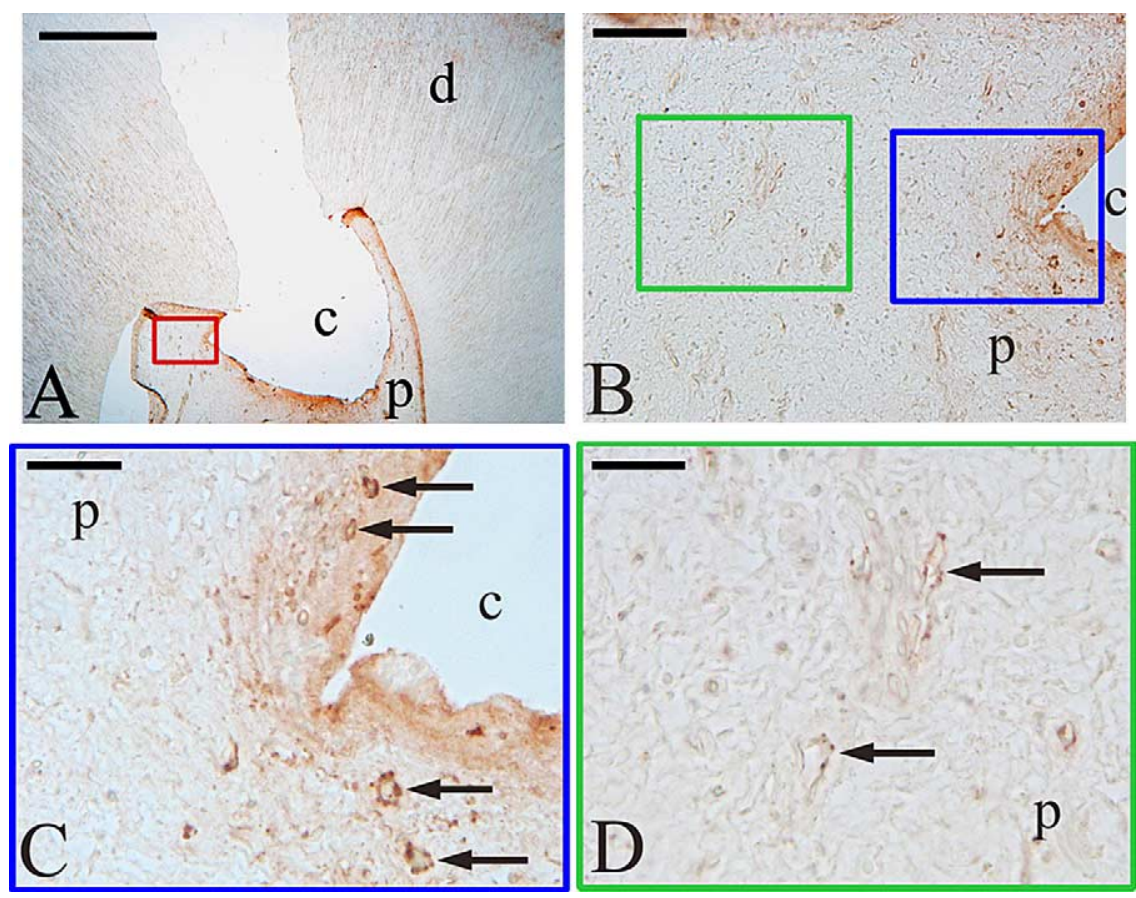

Figure 2 Stem cells proliferation exhibits a gradient after pulpal cavity preparation. After culture for 1 day with BrdU, the labelling was localised in the nuclei of cells in the perivascular area. The BrdU-immunolabelling exhibited a gradient. It was strong in the blood vessels surrounding the cavity ( $B$ and $C$ ) and decreased in those away from the cavity (B, D). Abbreviations: c: cavity; d: dentine; p: pulp; arrows indicate vessels. Scale bars in (A) $1 \mathrm{~mm}$; (B) $100 \mu \mathrm{m}$; (C and D) $50 \mu \mathrm{m}$. 

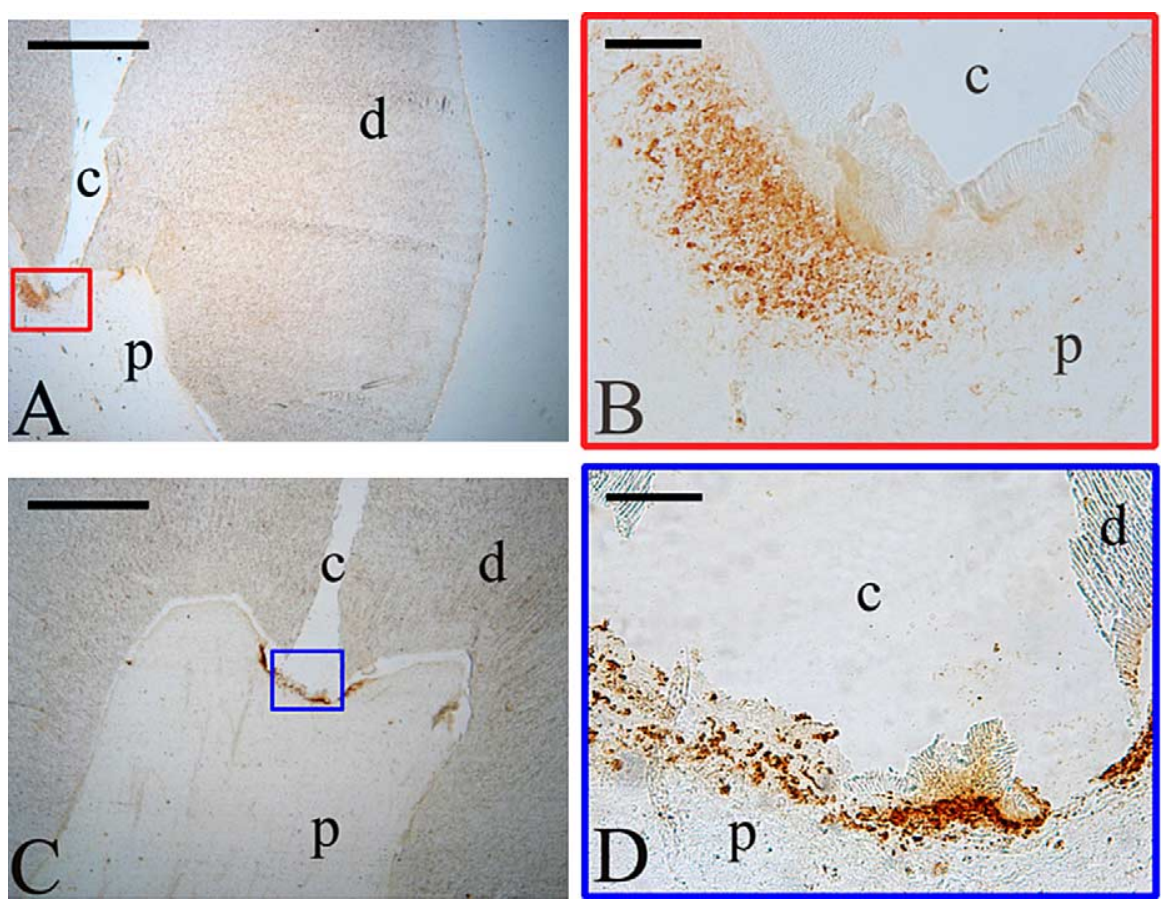

Figure 3 Cells migration after pulpal cavities preparations. The teeth were incubated in the BrdU-containing medium for 1 day and then the BrdU was removed and the teeth were incubated without BrdU for 2 weeks or 4 weeks. After 2 weeks, labelled cells were seen out of the blood vessels in the vicinity of the cavity (A and B). At 4 weeks, the immunolabelling was localised at the cavity area only ( $C$ and $D)$. Abbreviations: c: cavity; d: dentine; p: pulp. Scale bars in (A and C) $1 \mathrm{~mm}$; (B and D) $100 \mu \mathrm{m}$.

nolabelling exhibited a gradient. It was strong in the blood vessels surrounding the pulpal cavity and decreased in those away from the cavity (Fig. 2).

\section{Progenitor/stem cell migration}

After incubation for 2 weeks, labelled cells were seen distinct from the blood vessels in the vicinity of the cavity. At 4 weeks, the immunolabelling was localised to the cavity area only (Fig. 3).

\section{Control teeth}

Teeth cultured without or with dentine cavities did not show any perivascular labelling (Fig. 4).

\section{Discussion}

The ability of the dentine-pulp complex to respond to a variety of pathological conditions and injury by localised deposition of a tertiary dentine matrix has been long recognised. Mild injuries stimulate the surviving post-mitotic odontoblasts at the site of injury to up-regulate their synthetic and secretory activities to secrete a reactionary dentine matrix. ${ }^{5,6}$ Factor(s) and signalling molecules similar to those involved in physiological dentinogenesis, including TGF $\beta$ s, IGF-I and -II, members of BMP family and FGF family of signalling molecules, are involved in mediating the increased activities of odontoblasts during reactionary dentinogenesis. ${ }^{4,6}$

On the other hand, in pathological conditions that cause odontoblast death, the dentine regeneration occurs through reparative dentine secretion by a new generation of odontoblast-like cells. ${ }^{4,11}$ Therefore, unlike reactionary responses, reparative dentinogenesis is a more complex sequence of biological process, which is dependent on multiple factors, including the presence of responsive progenitor cells as well as the appropriate inductive molecular signals for induction of proliferation, migration and differentiation of the new generation of odontoblast-like cells.

The underlying cellular and molecular mechanisms regulating the sequence of events leading to reparative dentinogenesis have been the subject of intense investigation using a variety of in vitro and in vivo approaches. ${ }^{4,6,8}$ Although these studies have provided valuable information regarding the dentinogenic capacity of dental pulp cells, there is nevertheless little information about the initial steps of this process, particularly the proliferation and migration of progenitor cells that precede reparative dentine secretion. 


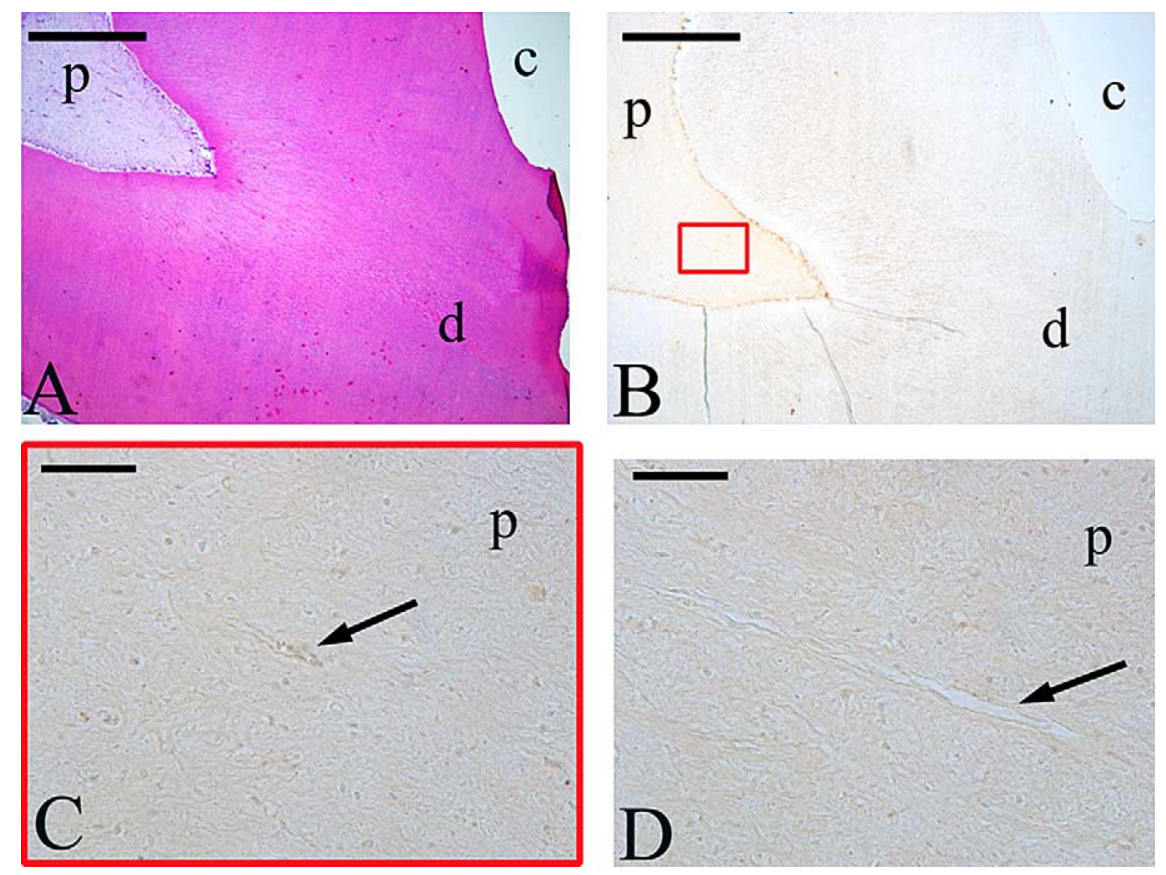

Figure 4 Proliferation control after dentine cavity preparation. The teeth cultured with BrdU for 1 day were used to control the specificity of the proliferation observed with the pulpal cavities. No perivascular immunolabelling was observed. Abbreviations: c: cavity; d: dentine; p: pulp; arrows indicate vessels. Scale bars in (A and B) $1 \mathrm{~mm}$; (C and D) $50 \mu \mathrm{m}$.

The primary finding of this study is the activation of human pulpal progenitor/stem cells in response to injury. This was demonstrated by the close correlation between the injury site and the intensity of the labelling, which was stronger in the vicinity of the injury and decreased away from it. After proliferation of the progenitor cells, migration to the injury site was necessary to provide pulp protection by the production of the hard tissue of reparative dentine at the injury site. Consistently, this work shows that these cells migrated to the injury site to replace the necrotic odontoblasts.

The ability of the dental pulp to give rise to new generations of odontoblast-like cells secreting reparative dentine suggests that populations of competent progenitor cells similar to the embryonic dental papilla reside within the dental pulp isolated from post-natal mice. ${ }^{12}$ Whether more than one sub-population of progenitor/stem cells exists in the pulp, their embryonic derivation and their potentialities are all questions remaining to be answered.

In addition to giving rise to odontoblasts, transplantation studies have shown that pulp cells can give rise to chondrocytes and osteoblasts secreting cartilage- and bone-like matrices, respectively. ${ }^{13}$ The multiple developmental potentials of the dental pulp are consistent with previous observations in various experimental animals ${ }^{3,12,14-16}$ and suggest that the dental pulp from post-natal mice, similar to human dental pulp ${ }^{7,9}$ contains progenitor/stem cells. Recently, these progenitor/post-natal stem cells were localised to the perivascular area of human pulp, ${ }^{10}$ although other localisations and derivations cannot be excluded.

In agreement with these data, our study clearly demonstrates that the pulpal injury stimulated the proliferation of progenitor/stem cells localised in the perivascular area. These progenitor/stem cells proliferated in their tissue of origin and responded by migration to the pulpal injury site. Although we did not investigate the differentiation of the migrating cells, this work allows us to distinguish between pulpal (with pulpal exposure) and dentinal (unexposed) cavities. These data reflect the situation in vivo where pulpal injury, but not dentine injury, leads to the proliferation, migration and differentiation of odontoblast-like cells from the pulp leading to the secretion of reparative dentine.

Further studies are needed to investigate the differentiation of these cells as well as the behaviour of the remaining odontoblasts and other pulpal cells after whole tooth culture.

This tooth culture system may be useful in the future as a model for studying the mechanisms underlying dentine regeneration and provides a potential model for the evaluation of biomaterials in restorative dentistry. 
1. Linde A, Goldberg M, Dentinogenesis. Crit Rev Oral Biol Med 1993;4:679-728.

2. Ruch JV, Lesot $\mathrm{H}$, Begue-Kirn C. Odontoblast differentiation. Int J Dev Biol 1995;39:51-68.

3. Tziafas D. Basic mechanisms of cytodifferentiation and dentinogenesis during dental pulp repair. Int J Dev Biol 1995; 39:281-90.

4. Tziafas $D$, Smith AJ, Lesot $H$. Designing new treatment strategies in vital pulp therapy. J Dent 2000;28:77-92.

5. Smith AJ, Cassidy M, Perry H, Begue-Kirn C, Ruch JV, Lesot H. Reactionary dentinogenesis. Int J Dev Biol 1995;39:273-80.

6. Smith AJ, Lesot $\mathrm{H}$. Induction and regulation of crown dentinogenesis: embryonic events as a template for dental tissue repair? Crit Rev Oral Biol Med 2001;12:425-37.

7. Gronthos S, Brahim J, Li W, Fisher LW, Cherman N, Boyde A, et al. Stem cell properties of human dental pulp stem cells. $J$ Dent Res 2002;81(8):531-5.

8. About I, Bottero MJ, De Denato P, Camps J, Franquin JC, Mitsiadis TA. Human dentin production in vitro. Exp Cell Res 2000;258:33-41.

9. Gronthos S, Mankani M, Brahim J, Gehron Robey P, Shi S. Postnatal human dental pulp stem cells (DPSCs) in vitro and in vivo. PNAS 2000;97(25):13625-30.
10. Shi S, Gronthos S. Perivascular niche of postnatal mesenchymal stem cells in human bone marrow and dental pulp. $J$ Bone Miner Res 2003;18(4):696-704.

11. Tziafas D, Alvanou A, Panagiotakopoulos N, Smith AJ, Lesot $\mathrm{H}$, Komnenou $\mathrm{A}$, et al. Induction of odontoblast-like cell differentiation in dog dental pulps after in vivo implantation of dentine matrix components. Arch Oral Biol 1995;40: 883-93.

12. Yamamura T. Differentiation of pulpal cells and inductive influences of various matrices with reference to pulpal wound healing. J Dent Res 1995;64:530-40.

13. Braut A, Kollar EJ, Mina M. Analysis of the odontogenic and osteogenic potentials of dental pulp in vivo using a Col1a1-2.3-GFP transgene. Int J Dev Biol 2003;47: 281-92.

14. Nakashima M. Dentin induction by implants of autolyzed antigen-extracted allogenic dentin on amputated pulps of dogs. Endod Dent Traumatol 1989;5:279-86.

15. Rutherford RB, Wahle J, Tucker M, Rueger D, Charette $M$. Induction of reparative dentine formation in monkeys by recombiant human osteogenic protein-1. Arch Oral Biol 1993;38:571-6.

16. Rutherford RB, Spangberg L, Tucker M, Rueger D, Charette $M$. The time-course of the induction of reparative dentine formation in mokeys by recombinant human osteogenic protein1. Arch Oral Biol 1994;39:833-8. 